\title{
NITROGEN RATES AND SIDE-DRESSING TIMING ON SWEET CORN SEED PRODUCTION AND PHYSIOLOGICAL POTENTIAL ${ }^{1}$
}

\author{
CLAUDEMIR ZUCARELI²*, JOSÉ HENRIQUE BIZZARRI BAZZO², JOSEMEYRE BONIFÁCIO SILVA², DENIS \\ SANTIAGO COSTA ${ }^{3}$, INÊS CRISTINA BATISTA FONSECA ${ }^{2}$
}

\begin{abstract}
Sweet corn is an important crop because of its seeds with high total sugar and low starch contents. As common corn, this group requires an adequate amount of nitrogen to reach high yields. However, the studies on nitrogen and sweet corn are performed for ear yield instead of seed yield. As seeds are the main propagation method for this species, we proposed to evaluate the effects of nitrogen rates as side-dressing at different plant stages of a sweet corn seed production. Sweet corn seeds (variety BR 400) were sown in Latosol (Oxisol), and a $3 \times 2+1$ factorial scheme was designed with three nitrogen rates $\left(40,80\right.$, and $\left.120 \mathrm{~kg} \mathrm{ha}^{-1}\right)$ at two plant stages $\left(\mathrm{V}_{6}\right.$ and $\left.\mathrm{R}_{1}\right)$ plus the control (no nitrogen side-dressing). The evaluated variables were seed yield, protein content, $\mathrm{P}$ and $\mathrm{Zn}$ contents, germination, and vigor rates. We concluded that nitrogen applied at a rate of $120 \mathrm{~kg} \mathrm{ha}^{-1}$ at $\mathrm{V}_{6}$ increases seed yield and maintains unaltered the protein content in seeds of sweet corn (BR 400 variety). Neither germination nor seed vigor increases when nitrogen rates are increased or administered at different stages of plant development. We also noted a slight decrease in $\mathrm{P}$ content or an increase in $\mathrm{Zn}$ content of seeds at low nitrogen rates; however, they are insufficient to promote changes in the physiological potential of sweet corn seeds.
\end{abstract}

Keywords: Zea mays. Yield. Protein content. Germination. Vigor.

\section{DOSES DE NITROGÊNIO E ÉPOCA DE COBERTURA PARA PRODUÇÃO E POTENCIAL FISIOLÓGICO DE SEMENTES EM MILHO DOCE}

\begin{abstract}
RESUMO - O milho doce é uma cultura importante por causa do seu tipo de sementes com índice elevado dos açúcares totais e baixo índice do amido. Como o milho comum, este necessita de quantidade adequada de nitrogênio para atingir altas produtividades, no entanto, os estudos que envolvem nitrogênio e milho doce são realizados para o rendimento das espigas e não para a produção de sementes. Como a semente é o principal método de propagação dessa espécie, foi avaliado os efeitos das doses de nitrogênio em cobertura em diferentes estádios fenológicos para produção e potencial fisiológico de sementes de milho doce. As sementes de milho doce (variedade BR 400) foram semeadas em Latossolo e um esquema fatorial de tratamento $3 \times 2+1$ foi instalado com três doses de nitrogênio 40,80 e $120 \mathrm{~kg} \mathrm{ha}^{-1}$ e dois estádios fenológicos $\left(\mathrm{V}_{6}\right.$ e $\left.\mathrm{R}_{1}\right)$ mais o controle (sem nitrogênio em cobertura). Foram avaliadas a produtividade de sementes, teores de proteína, $\mathrm{P}$ e $\mathrm{Zn}$, germinação e vigor. Como conclusão, o nitrogênio fornecido em $\mathrm{V}_{6}$ a $120 \mathrm{~kg} \mathrm{ha}^{-1}$ aumenta a produtividade de sementes e mantém os teores de proteína inalterados. A germinação da semente e o vigor não aumentam quando as taxas de nitrogênio são acrescidas ou fornecidas em diferentes estádios fenológicos. Diminuição ligeira do teor de $\mathrm{P}$ ou o aumento do teor de $\mathrm{Zn}$ nas sementes são observados a uma dose baixa de nitrogênio entretanto não suficientes para promover alterações no potencial fisiológico das sementes do milho doce.
\end{abstract}

Palavras-chave: Zea mays. Produtividade. Teor de proteína. Germinação. Vigor.

\footnotetext{
${ }^{*}$ Corresponding author

${ }^{1}$ Received for publication in 01/24/2017; accepted in 05/09/2017.

${ }^{2}$ Departement of Afronomy, Agrarian Sciences Center, Universidade Estadual de Londrina, Londrina, PR, Brazil; claudemircca@uel.br, agro.bazzo@gmail.com, josibonifacio@uel.br, inescbf@uel.br.

${ }^{3}$ Instituto Federal de Educação, Ensino e Tecnologia de Mato Grosso do Sul, Nova Andradina, MS, Brazil; denis.costa@ifms.edu.br.
} 


\section{INTRODUCTION}

Sweet corn (Zea mays L.), Saccharata group, is a plant with potential to contribute to energy generation by plant biomass (BARROS-RIOS et al., 2015) and can produce seeds with high total sugar and low starch contents, enhancing its quality for human consumption, both in natura or processed (KWIATKOWSKI; CLEMENTE; SCAPIM, 2011). When compared to common corn, this group has mutant alleles blocking sugar conversion to starch, increasing the total contents in seeds (JHA; SINGH; AGRAWAL, 2016).

For Z. mays plants, nitrogen is an important macronutrient for being one of the most accumulated in plants during their development, only requiring a supplementary addition via side-dressing to reach high yields (OKUMURA et al., 2014). Corn plants with a high level of nitrogen increase leaf sugar concentration, dry weight, photosynthesis rate and $\mathrm{CO}_{2}$ assimilation, resulting in adequate physiological status (JIN et al., 2015). Also, some studies have reported an increase in grain protein contents by applying high levels of nitrogen either as side-dressing at vegetative stage or at late stages (at silking), improving corn nutritional quality (SILVA et al., 2005; SHARIFI; NAMVAR, 2016).

Protein accumulation in seeds is important because they represent the first source of amino acids within the first hours of imbibition, as free amino acids in dry seeds are insufficient for protein synthesis (BEWLEY et al., 2013). In Z. mays, the accumulation of storage proteins occurs during the early stages of endosperm development, being retained until later stages in the endoplasmic reticulum, protein bodies, or in aleurone cells (REYES et al., 2011). Therefore, the high protein content in seeds can represent a beneficial balance of amino acids in seeds, enhancing seed development speed and uniformity.

Besides protein content, nitrogen has the potential to affect the balance of other nutrients, such as phosphorus and zinc content (MALAVOLTA; VITTI; OLIVEIRA, 1997). Both nutrients (P and $\mathrm{Zn)}$ are essential for seedling establishment and initial growth. As suggested by White and Veneklaas (2012), seed P content is the only source of this mineral available for the initial growth of seedlings. Additionally, Boonchuay et al. (2013) observed a progressive increase in seedling weight with $\mathrm{Zn}$ increment in seeds of rice.

Although there are studies on nitrogen management for common corn (LEAL et al., 2013; VALDERRAMA et al., 2014), little is known about sweet corn (Saccharata group), which has seeds with different properties; hence, more results on the optimal rate and plant stage for nitrogen application are missing. According to Cruz et al. (2015), nitrogen as a side-dressing in sweet corn increase the number of commercial ears; however, these authors made no relationship between it and seed yield and nutritional aspect of seeds, such as protein accumulation, nutritional balance, and seed physiological potential.

Thus, there is little information when the subject is nitrogen management and sweet corn seed production, mainly concerning seed yield, protein content, nutritional balance, and physiological potential. Based on the hypothesis that the nitrogen can improve seed yield, protein content, phosphorus/ zinc contents, and seed physiological potential, we proposed to evaluate the effects of nitrogen rates as side-dressing applied at different plant stages in sweet corn plants.

\section{MATERIAL AND METHODS}

Sweet corn seeds (variety BR 400, super sweet brittle 1) were sown in an area belonging to the State University of Londrina. The local soil is classified as first level by the IUSS working group WRB (2015), being a Ferralsol. Local weather is classified by Köppen-Geiger's classification as Cfa (temperate without dry season and hot summers). The area was previously grown with wheat and the soil chemical properties determined within 0.0-0.2 $\mathrm{m}$ depth. The analysis results are as follow: $\mathrm{pH}\left(\mathrm{CaCl}_{2}\right)=5.00, \mathrm{H}+\mathrm{Al}=3.42 \mathrm{cmol}_{\mathrm{c}} \mathrm{dm}^{-3}$, $\mathrm{Ca}=9.77 \mathrm{cmol}_{\mathrm{c}} \mathrm{dm}^{-3}, \mathrm{Mg}=1.76 \mathrm{cmol}_{\mathrm{c}} \mathrm{dm}^{-3}$; $\mathrm{K}=0.84 \mathrm{cmol}_{\mathrm{c}} \mathrm{dm}^{-3}, \mathrm{P}=14.49 \mathrm{mg} \mathrm{dm}^{-3}$, and organic matter $=28.60 \mathrm{~g} \mathrm{dm}^{-3}$. Based on Oliveira (2003), the sowing fertilization rates were $30 \mathrm{~kg} \mathrm{ha}^{-1} \mathrm{~N}$, $40 \mathrm{~kg} \mathrm{ha}^{-1} \mathrm{P}_{2} \mathrm{O}_{5}$, and $40 \mathrm{~kg} \mathrm{ha}^{-1} \mathrm{~K}_{2} \mathrm{O}$.

Seed sowing was made at the rate of 7 seeds per row meter spaced in $0.9 \mathrm{~m}$ to reach the plant population recommend for BR 400 (70,000 plants/ha). The growing was carried out during spring, as shown in Figure 1.

The study was performed in a randomized complete block design, in a $3 \times 2+1$ factorial scheme with four replications. Treatments consisted of a combination of three (3) nitrogen rates applied as side-dressing (40, 80, and $\left.120 \mathrm{~kg} \mathrm{ha}^{-1}\right)$ at two (2) plant stages $\left(\mathrm{V}_{6}\right.$ stage: at least $50 \%$ plants with six leaves; $\mathrm{R}_{1}$ stage - silking: at least $75 \%$ plants showing ears with visible stigmas) plus a control (no nitrogen application). The experimental unit area (plot) was $18 \mathrm{~m}^{2}(5.0 \mathrm{~m} \times 3.6 \mathrm{~m})$, and the useful area for yield estimation was $7.2 \mathrm{~m}^{2}(4.0 \mathrm{~m} \times 1.8 \mathrm{~m})$. The nitrogen source used on side-dressing was urea $\mathrm{CO}$ $\left(\mathrm{NH}_{2}\right)_{2}$, and plant development stages identified as proposed by Ritchie, Hanway and Benson (1993). During plant development, soil moisture, weeds, diseases, and pest were controlled as recommended to guarantee a great plant development. When seeds reached $20 \%$ moisture, ears were harvested and seeds dried until 13\%. 


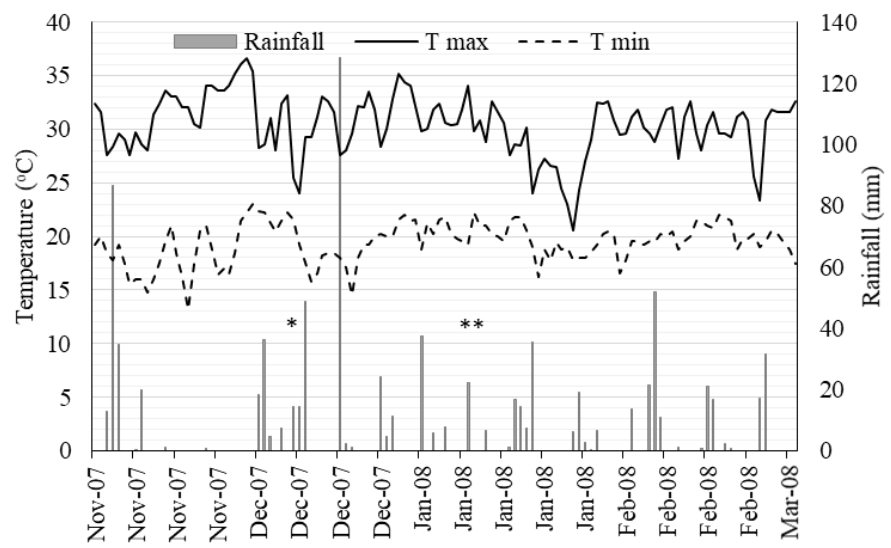

Figure 1. Weather data during spring season on the campus of the State University of Londrina, located at $51^{\circ} 11^{\prime} \mathrm{E}$, $23^{\circ} 23$ 'S , and $560 \mathrm{~m}$ above sea level (*N fertilization at vegetative stage; $* * \mathrm{~N}$ fertilization at reproductive stage).

The analyzed parameters followed the following procedures: Seed yield - determined for seeds with $13 \%$ moisture and harvested from the useful area. Germination - 50 seeds from each treatment were sown on 3 sheets of towel paper and kept at $25{ }^{\circ} \mathrm{C}$ for seven days (single counting); the number of normal seedlings was determined as proposed by Rules for Seed Testing (BRASIL, 2009) with results expressed in percentage. Accelerated aging - 50 seeds from each treatment were placed on a stainless screen inside closed boxes $(0.03 \times 0.03 \times 0.11 \mathrm{~m})$ filled with $40 \mathrm{~mL}$ distilled water. The set was kept at $42{ }^{\circ} \mathrm{C}$ for $72 \mathrm{~h}$, according to Santos et al. (2002); then, the germination testing was performed as previously described. Protein content - seed samples from each treatment were dried in an oven $\left(65^{\circ} \mathrm{C}\right)$ until obtaining constant mass. Afterward, total nitrogen was determined for each seed sample according to Malavolta, Vitti and Oliveira (1997), and the results expressed as proposed in the Kjeldahl method where protein content is estimated based on total nitrogen content $\times 6.25$ (conversion factor). $\mathrm{P}$ and $\mathrm{Zn}$ were analyzed by acid digestion with a nitropercloric mixture in a block digester, being analyzed by spectrophotometry, as proposed by Malavolta, Vitti and Oliveira (1997).

Data analysis was performed with a complex treatment structure using multiple contrast tests, according to Schaarschmidt and Vaas (2009). In this analysis, contrasts are determined to perform comparisons between the most interesting variables (Table 1). The contrasts consisted of the null hypothesis $\left(\mathrm{H}_{0}\right)$ : $\mathbf{A}$ : there is no difference between control and any nitrogen rate (contrasts 1 to 6 ); $\mathbf{B}$ : there is no difference among nitrogen rates applied at $\mathrm{V}_{6}$ stage (contrasts 7 to 9 ); $\mathbf{C}$ : there is no difference among nitrogen rates applied at $\mathrm{R}_{1}$ stage (contrasts 10 to 12 ); $\mathbf{D}$ : there is no difference among nitrogen rates applied at $V_{6}$ stage or at $R_{1}$ stage (contrasts 13 to 15 ).

\section{RESULTS AND DISCUSSION}

In general, treatments showed low seed yields because the study was carried out with the variety BR 400 (Table 2). It is an open-pollinated variety still important for small farmers and has good acceptability but low yield compared with hybrids. The environmental conditions were good for plant development with a total rainfall of $853 \mathrm{~mm}$ (well distributed) and mean temperature of $24.9{ }^{\circ} \mathrm{C}$. According to Albuquerque (2010), corn plant requires from $380 \mathrm{~mm}$ to $550 \mathrm{~mm}$ water to complete the cycle.

Seed $\mathrm{P}$ contents were slightly higher than those observed by White and Veneklass (2012) in common corn. These authors stated that $75.6 \%$ of the total $\mathrm{P}$ in seeds is in phytin compounds, which make an important source of $\mathrm{P}$ during plant initial development. Seed Zn content was slightly higher than that observed by Jin et al. (2013). For Alscher, Erturk and Health (2002), zinc is a constituent of an isoform of superoxide dismutase, an enzyme able to transform the superoxide radical into hydrogen peroxide.

For seed physiological potential (Table 2), we observed low normal seedlings evaluated by germination and accelerated aging tests, what is normal for this group of Zea mays. According to Wilson-Junior and Mohan (1998), for sweet corn sh-2, the main problem for seed vigor is the extreme levels of sucrose, which results in an embryo sugar imbalance and membrane disruption, producing seed lots with poor vigor. In addition, we observed a slight increase in accelerated aging results. It could have occurred because of a thermic and humid treatment, which increases the number of normal seedlings by decreasing germination reducer microorganisms or by promoting similar effects of seed priming. 
Table 1. Contrast coefficient of the 15 comparisons proposed to perform this study.

\begin{tabular}{|c|c|c|c|c|c|c|c|c|}
\hline \multirow{4}{*}{$\begin{array}{l}\text { Contrast } \\
\text { number }{ }^{1}\end{array}$} & \multirow{4}{*}{ Comparison } & \multicolumn{7}{|c|}{ Contrast Coefficient } \\
\hline & & \multirow{3}{*}{$\begin{array}{c}\text { Control } \\
---- \\
0 \\
\end{array}$} & \multicolumn{3}{|c|}{$\mathrm{V}_{6}$} & \multicolumn{3}{|c|}{$\mathrm{R}_{1}$} \\
\hline & & & ---- & $\mathrm{kg} \mathrm{I}$ & $h a^{-1}$ & ----- & ---- & \\
\hline & & & 40 & 80 & 120 & 40 & 80 & 120 \\
\hline 1 & Control $\times 40 \mathrm{~kg} \mathrm{~N} \mathrm{ha}^{-1}\left(\mathrm{~V}_{6}\right)$ & 1 & -1 & 0 & 0 & 0 & 0 & 0 \\
\hline 2 & Control $\times 80 \mathrm{~kg} \mathrm{~N} \mathrm{ha}^{-1}\left(\mathrm{~V}_{6}\right)$ & 1 & 0 & -1 & 0 & 0 & 0 & 0 \\
\hline 3 & Control $\times 120 \mathrm{~kg} \mathrm{~N} \mathrm{ha}^{-1}\left(\mathrm{~V}_{6}\right)$ & 1 & 0 & 0 & -1 & 0 & 0 & 0 \\
\hline 4 & Control $\times 40 \mathrm{~kg} \mathrm{~N} \mathrm{ha}^{-1}\left(\mathrm{R}_{1}\right)$ & 1 & 0 & 0 & 0 & -1 & 0 & 0 \\
\hline 5 & Control $\times 80 \mathrm{~kg} \mathrm{~N} \mathrm{ha}^{-1}\left(\mathrm{R}_{1}\right)$ & 1 & 0 & 0 & 0 & 0 & -1 & 0 \\
\hline 6 & Control $\times 120 \mathrm{~kg} \mathrm{~N} \mathrm{ha}^{-1}\left(\mathrm{R}_{1}\right)$ & 1 & 0 & 0 & 0 & 0 & 0 & -1 \\
\hline 7 & $40 \mathrm{~kg} \mathrm{~N} \mathrm{ha}^{-1} \times 80 \mathrm{~kg} \mathrm{~N} \mathrm{ha}^{-1}\left(\mathrm{~V}_{6}\right)$ & 0 & 1 & -1 & 0 & 0 & 0 & 0 \\
\hline 8 & $40 \mathrm{~kg} \mathrm{~N} \mathrm{ha}^{-1} \times 120 \mathrm{~kg} \mathrm{~N} \mathrm{ha}^{-1}\left(\mathrm{~V}_{6}\right)$ & 0 & 1 & 0 & -1 & 0 & 0 & 0 \\
\hline 9 & $80 \mathrm{~kg} \mathrm{~N} \mathrm{ha}^{-1} \times 120 \mathrm{~kg} \mathrm{~N} \mathrm{ha}^{-1}\left(\mathrm{~V}_{6}\right)$ & 0 & 0 & 1 & -1 & 0 & 0 & 0 \\
\hline 10 & $40 \mathrm{~kg} \mathrm{~N} \mathrm{ha}^{-1} \times 80 \mathrm{~kg} \mathrm{~N} \mathrm{ha}^{-1}\left(\mathrm{R}_{1}\right)$ & 0 & 0 & 0 & 0 & 1 & -1 & 0 \\
\hline 11 & $40 \mathrm{~kg} \mathrm{~N} \mathrm{ha}^{-1} \times 120 \mathrm{~kg} \mathrm{~N} \mathrm{ha}^{-1}\left(\mathrm{R}_{1}\right)$ & 0 & 0 & 0 & 0 & 1 & 0 & -1 \\
\hline 12 & $80 \mathrm{~kg} \mathrm{~N} \mathrm{ha}^{-1} \times 120 \mathrm{~kg} \mathrm{~N} \mathrm{ha}^{-1}\left(\mathrm{R}_{1}\right)$ & 0 & 0 & 0 & 0 & 0 & 1 & -1 \\
\hline 13 & $40 \mathrm{~kg} \mathrm{~N} \mathrm{ha}^{-1}\left(\mathrm{~V}_{6}\right) \times 40 \mathrm{~kg} \mathrm{~N} \mathrm{ha}^{-1}\left(\mathrm{R}_{1}\right)$ & 0 & 1 & 0 & 0 & -1 & 0 & 0 \\
\hline 14 & $80 \mathrm{~kg} \mathrm{~N} \mathrm{ha}^{-1}\left(\mathrm{~V}_{6}\right) \times 80 \mathrm{~kg} \mathrm{~N} \mathrm{ha}^{-1}\left(\mathrm{R}_{1}\right)$ & 0 & 0 & 1 & 0 & 0 & -1 & 0 \\
\hline 15 & $120 \mathrm{~kg} \mathrm{~N} \mathrm{ha}^{-1}\left(\mathrm{~V}_{6}\right) \times 120 \mathrm{~kg} \mathrm{~N} \mathrm{ha}^{-1}\left(\mathrm{R}_{1}\right)$ & 0 & 0 & 0 & 1 & 0 & 0 & -1 \\
\hline
\end{tabular}

${ }^{1}$ Data analysis was performed through Proc GLIMMIX, in SAS University Edition ${ }^{\circledR}$.

Table 2. Averages of seed yield, phosphorus and zinc contents, germination, and accelerated aging in sweet corn.

\begin{tabular}{|c|c|c|c|}
\hline Variety & Parameter & Average & Coefficient of variance \\
\hline \multirow{5}{*}{ BR 400} & Yield & $2234 \mathrm{~kg} / \mathrm{ha}$ & $10.5 \%$ \\
\hline & Seed P content & $5.3 \mathrm{~g} / \mathrm{kg}$ & $13.1 \%$ \\
\hline & Seed $\mathrm{Zn}$ content & $30.91 \mathrm{mg} / \mathrm{kg}$ & $11.3 \%$ \\
\hline & Germination & $75 \%$ & $7.8 \%$ \\
\hline & Accelerated aging & $83 \%$ & $10.5 \%$ \\
\hline
\end{tabular}

For contrasts 1 to 6 (Hypothesis $\mathbf{A}$ ), we observed a yield increment for $120 \mathrm{~kg} \mathrm{~N} h a^{-1}$ at $\mathrm{V}_{6}$ stage. With $95 \%$ confidence, nearly $287 \mathrm{~kg} \mathrm{ha}^{-1}$ increment in seed yield is expected under this rate and at this vegetative stage, showing the benefits brought by nitrogen as side-dressing in sweet corn. This result was confirmed with the ones observed for contrasts 7 to 9 (Hypothesis B), which identified a significant increment in seed yield when $120 \mathrm{~kg} \mathrm{~N} \mathrm{ha}^{-1}$ nitrogen was provided at $\mathrm{V}_{6}$ (Table 1 and Figure 2). When nitrogen was applied, at any rate, as side-dressing in the reproductive stage $R_{1}$ (contrast 10 to 12 of Hypothesis $\mathbf{C}$ ), there was no increment in seed yield; the application of $120 \mathrm{~kg} \mathrm{~N} \mathrm{ha}^{-1}$ at $\mathrm{R}_{1}$ decreased seed yield in
$267 \mathrm{~kg} \mathrm{ha}^{-1}$; therefore, we concluded no application should be performed during this stage.

The optimal nitrogen rate in sweet corn is variable since there are many responsive varieties and hybrids, which show different yields. In this study, we used a variety (BR 400) with low yield potential compared to hybrids but still important for low-income farmers, unable to buy hybrid seeds. There is no specific nitrogen recommendation for sweet corn; however, we observed that $80 \mathrm{~kg} \mathrm{~N} \mathrm{ha}^{-1}$ is suboptimal to improve seed yield and an increment was only reached for $120 \mathrm{~kg} \mathrm{~N} \mathrm{ha}^{-1} \mathrm{~N}$ at $\mathrm{V}_{6}$. A similar outcome was reported by Okumura et al. (2014), who found a rate of $110.84 \mathrm{~kg} \mathrm{~N} \mathrm{ha}^{-1}$ as optimal for sweet corn ear production. 


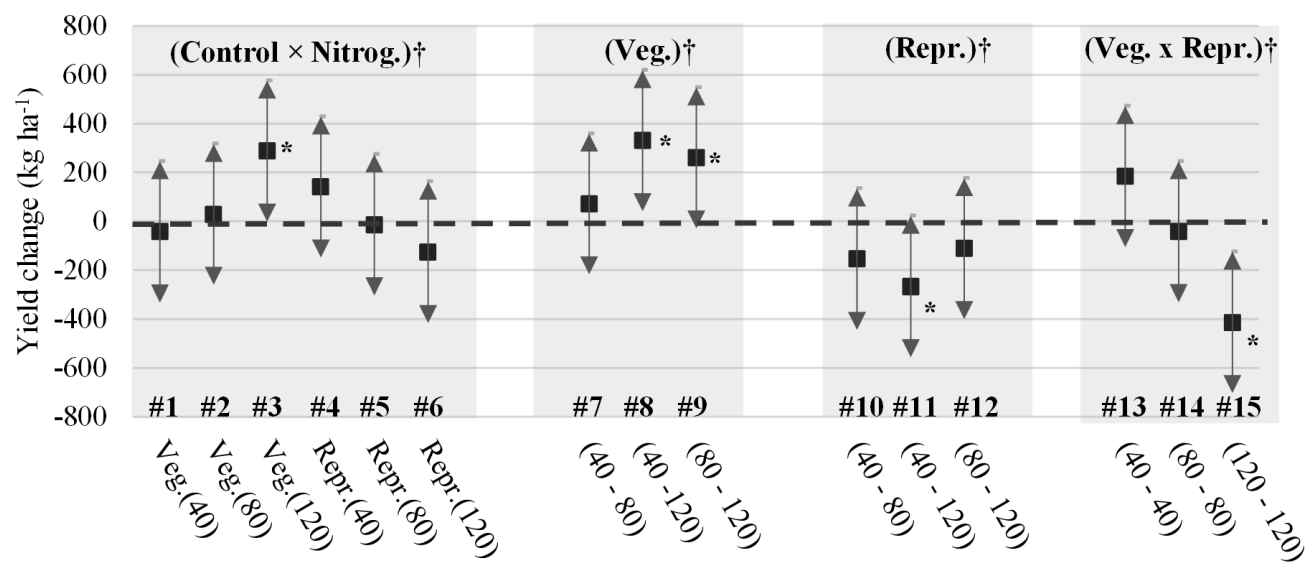

Figure 2. Increase/ decrease in seed yield expressed in simultaneous $95 \%$ confidence intervals for 15 contrasts (Table 1). Y-axis expresses the comparisons between control and each nitrogen rate (contrasts 1 to 6), among nitrogen rates at vegetative stage (contrasts 7 to 9), among nitrogen rates at reproductive stage (contrasts 10 to 12) and between each nitrogen rate at vegetative and reproductive (contrasts 13 to 15). $\dagger$ At least one significant contrast; *significant contrast at $5 \%$.

Seed protein content had no alteration for any tested contrast between nitrogen rates or plant stages in sweet corn (Figure 3). One hypothesis for this result is regarding the effect of genetic and environment interaction on this characteristic as Silva et al. (2005) observed different potential to accumulate crude protein in grains.

Seed $\mathrm{P}$ contents changed as a function of nitrogen rate and application timing (Figure 4A). At the optimal nitrogen dressing rate for yield
(120 $\mathrm{kg} \mathrm{N} \mathrm{ha}^{-1}$ in $\mathrm{V}_{6}$ ), no increment was observed in $\mathrm{P}$ and $\mathrm{Zn}$ contents, therefore, resulting in an equilibrated nutritional status. Conversely, the lower nitrogen rates (40 and $80 \mathrm{~kg} \mathrm{~N} \mathrm{ha}^{-1}$ in $\mathrm{V}_{6}$ ) resulted in smaller seed $\mathrm{P}$ contents (contrasts 1 and 2). This outcome was reaffirmed in contrasts 8 and 9 , where the rate of $120 \mathrm{~kg} \mathrm{~N}^{-1}$ resulted in higher seed $\mathrm{P}$ contents compared to the other rates (40 and $80 \mathrm{~kg} \mathrm{~N} \mathrm{ha}^{-1}$ in $\mathrm{V}_{6}$ ).

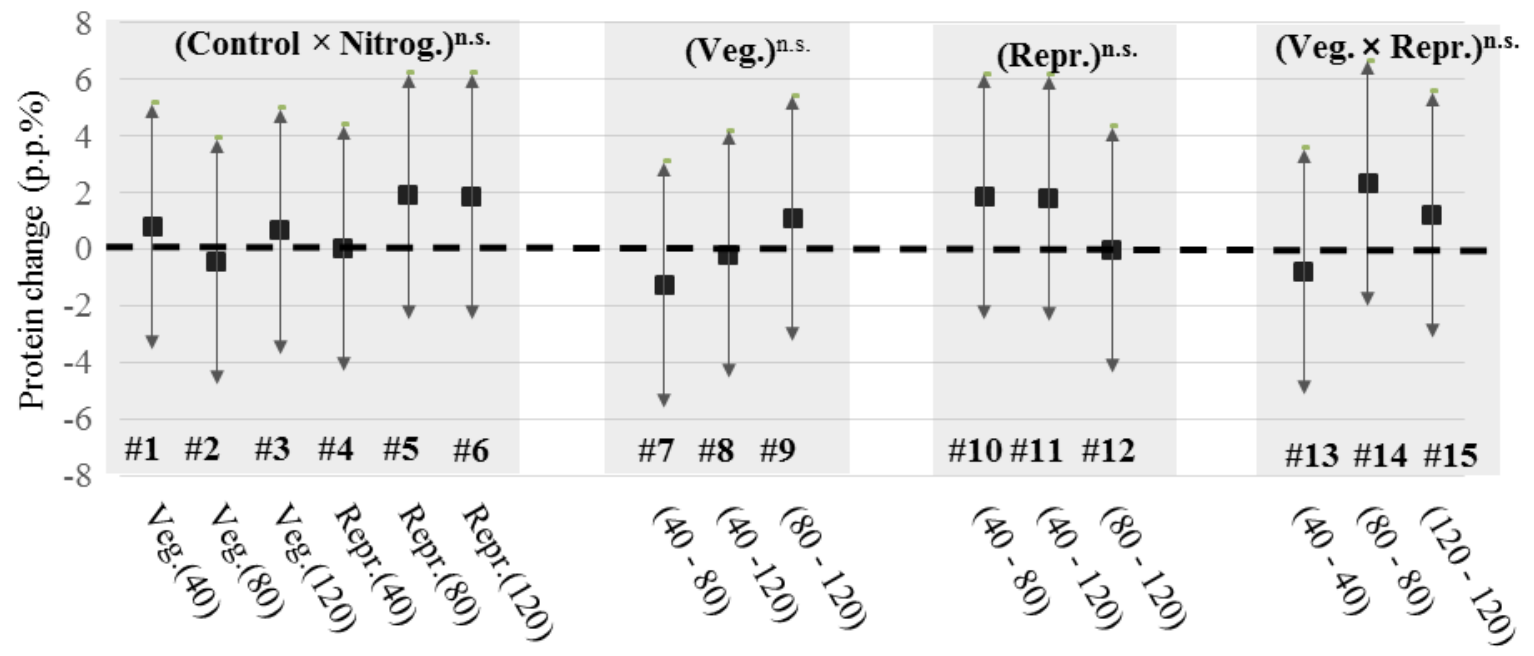

Figure 3. Increase/ decrease in protein content (percent point) expressed in simultaneous $95 \%$ confidence intervals for 15 contrasts (Table 1). Y-axis expresses the comparisons between control and each nitrogen rate (contrasts 1 to 6), among nitrogen rates at vegetative stage (contrasts 7 to 9), among nitrogen rates at reproductive stage (contrasts 10 to 12) and between each nitrogen rate at vegetative and reproductive (contrasts 13 to 15). $†$ At least one significant contrast; *significant contrast at $5 \%$.

The $\mathrm{Zn}$ content in seeds had no increment at the optimal nitrogen rate for yield $\left(120 \mathrm{~kg} \mathrm{~N} \mathrm{ha}^{-1}\right)$ (Figure 4B). In contrast, the lower rates (40 and 80 $\mathrm{kg} \mathrm{N} \mathrm{ha}{ }^{-1}$ in $\mathrm{V}_{6}$ ) promoted a slight increase in $\mathrm{Zn}$ contents (contrasts 1 and 2) for contrasts 8 and 9 , showing $\mathrm{Zn}$ content reductions in seed when the optimal rate was applied. The nitrogen application during reproductive stage $R_{1}$ increased $\mathrm{Zn}$ seed contents at 80 and $120 \mathrm{~kg} \mathrm{~N} \mathrm{ha}^{-1}$ (contrasts 5 and 6).

$\mathrm{P}$ and $\mathrm{Zn}$ are important for either seed germination or human nutrition. Moreover, $\mathrm{P}$ is a nutrient with benefits to seed germination because is 
part of the phytin molecule, which provides energy to start the germination process. On the other hand, $\mathrm{P}$ as part of the phytin molecule is nutritionally undesired since negatively charged phosphate groups can bind essential dietary minerals, such as zinc, calcium, and iron (BEWLEY et al., 2013).

For being a cofactor of many enzymes, when $\mathrm{Zn}$ is unavailable in the soil, the seed reserves are the main sources of this mineral for the first germination processes. Rengel and Graham (1995) observed a fast initial growth of wheat seedlings with high $\mathrm{Zn}$ contents if compared to those grown on a Zn-deficient soil. In this study, we concluded that even significant, these changes were insufficient to promote any alteration in seed quality.
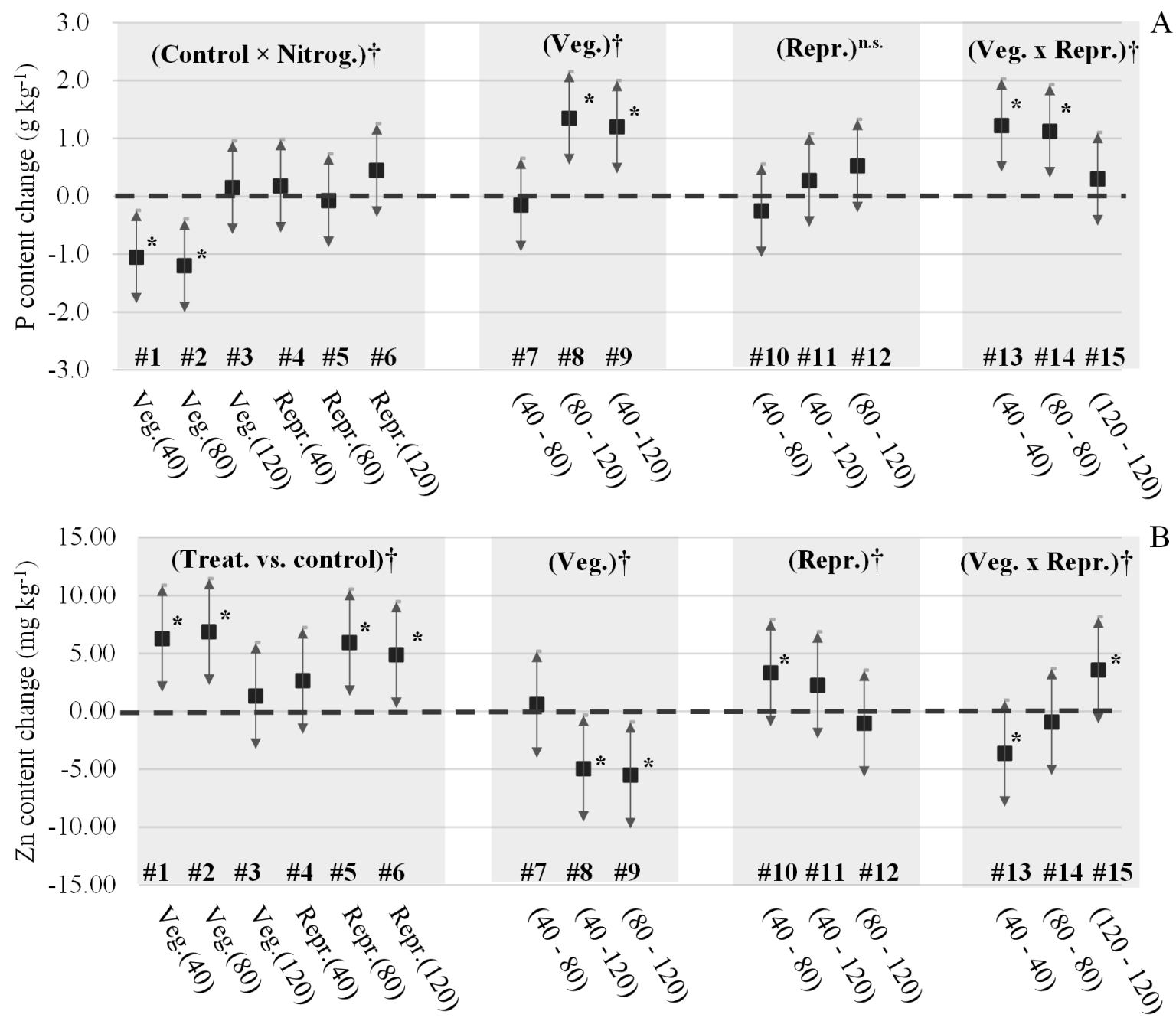

Figure 4. Phosphorus (A) and Zinc (B) contents in sweet corn seeds expressed in simultaneous 95\% confidence intervals for 15 contrasts (Table 1). Y-axis expresses the comparisons between control and each nitrogen rate (contrasts 1 to 6), among nitrogen rates at vegetative stage (contrasts 7 to 9), among nitrogen rates at reproductive stage (contrasts 10 to 12) and between each nitrogen rate at vegetative and reproductive (contrasts 13 to 15). $\dagger$ At least one significant contrast; * significant contrast at $5 \%$.

Concerning the physiological potential of seeds, neither rates nor the timing of nitrogen application had significant results (Figure $5 \mathrm{~A}$ and $5 \mathrm{~B})$. Even though slight changes in $\mathrm{P}$ and $\mathrm{Zn}$ contents were registered (Figure $4 \mathrm{~A}$ and $4 \mathrm{~B}$ ), corn seeds kept germination speed and vigor unaltered. On the one side, nitrogen has been related in the literature as an important nutrient to increase yield, on the other hand, for seed physiological potential, many studies have reported no relationships between nitrogen rates and seed germination/ vigor. Likewise, Zucareli et al. (2012) tested nitrogen rates in sweet corn and observed no increment in seed physiological potential, even at high rates.

In general, sweet corn had a good response to nitrogen rates, showing increments in seed yield and keeping seed physiological potential unaltered. Therefore, we recommend the application of nitrogen to produce sweet corn seeds with no germination and vigor damages. 

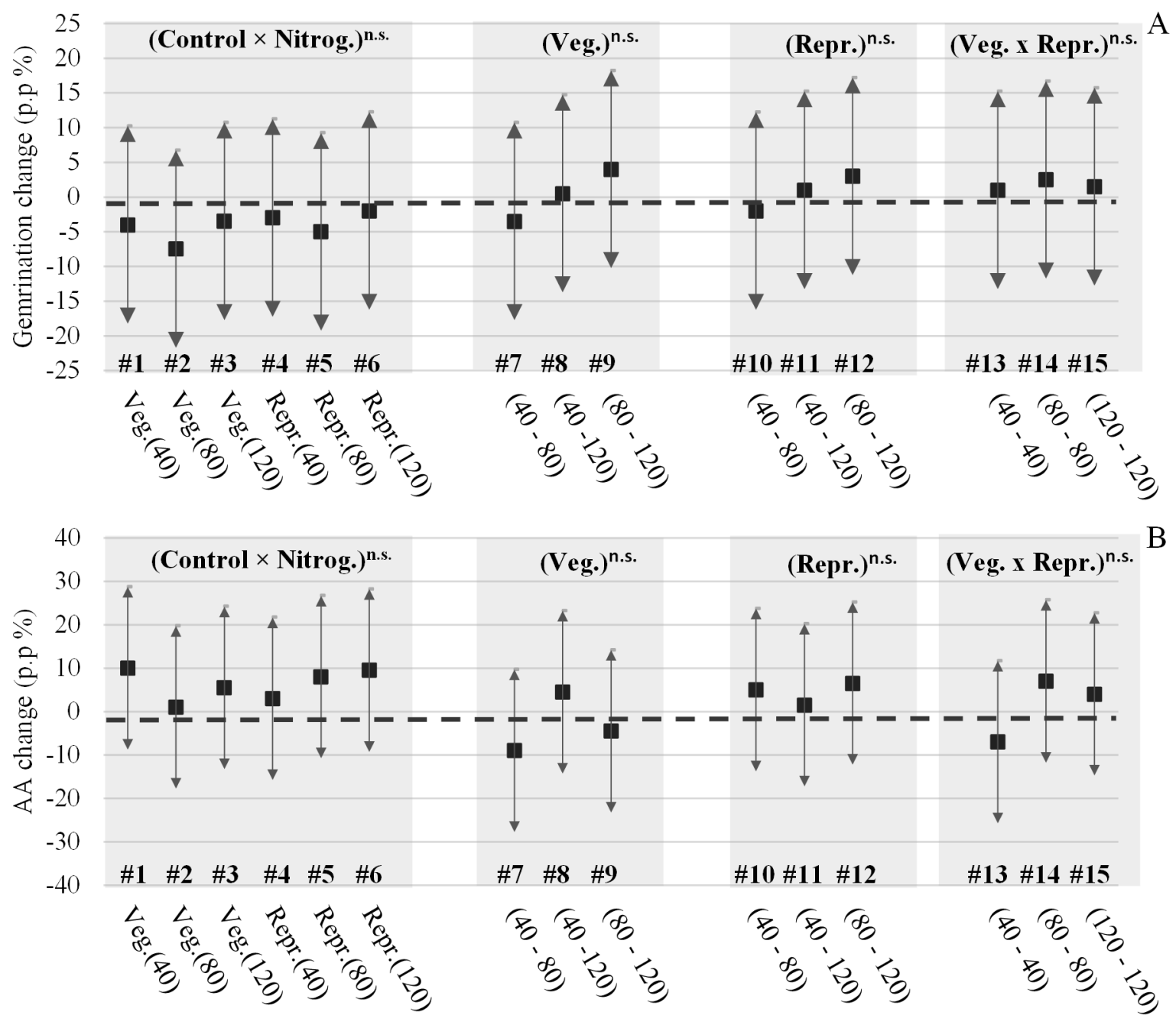

Figure 5. Variations in germination (A) and accelerated aging - AA (B) of sweet corn seeds (percent points) expressed in simultaneous $95 \%$ confidence intervals for 15 contrasts (Table 1). Y-axis expresses the comparisons between control and each nitrogen rate (contrasts 1 to 6), among nitrogen rates at vegetative stage (contrasts 7 to 9), among nitrogen rates at reproductive stage (contrasts 10 to 12) and between each nitrogen rate at vegetative and reproductive (contrasts 13 to 15 ). $\uparrow$ At least one significant contrast; *significant contrast at 5\%.

\section{CONCLUSION}

The application of $120 \mathrm{~kg} \mathrm{ha}^{-1}$ nitrogen at $\mathrm{V}_{6}$ increased seed yield and maintained the protein content unaltered in seeds of sweet corn BR 400 variety. Neither seed germination nor seed vigor increased with increasing nitrogen rates or application times. Smaller nitrogen rates promoted a slight decrease in $\mathrm{P}$ and increase in $\mathrm{Zn}$ contents in sweet corn seeds but insufficient to promote changes in their physiological potential.

\section{REFERENCES}

ALBUQUERQUE, P. E. P. Manejo da irrigação. Informe Agropecuário, Belo Horizonte, v. 31, n. 259, p. 14-17, 2010.

ALSCHER, R. G.; ERTURK, N.; HEATH, L. S.
Role of superoxide dismutases (SODs) in controlling oxidative stress in plants. Journal of experimental botany, Oxford, v. 53, n. 372, p. 1331-41, 2002.

BARROS-RIOS, J. et al. Biomass, sugar, and bioethanol potential of sweet corn. GCB Bioenergy, Malden, v. 7, n. 1, p. 153-160, 2015.

BEWLEY, J. D. et al. Seeds: physiology of development, germination and dormancy. New York, NY: Springer New York, 2013. 392 p.

BOONCHUAY, P. et al. Effect of different foliar zinc application at different growth stages on seed zinc concentration and its impact on seedling vigor in rice. Soil Science and Plant Nutrition, Tokyo, v. 59, n. 2, p. 180-188, 2013.

BRASIL. Ministério da Agricultura, Pecuária e Abastecimento. Regras para análise de sementes. Ministério da Agricultura, Pecuária e Abastecimento. 
Secretaria de Defesa Agropecuária. Brasília: MAPA/ ACS, 2009. 399 p.

CRUZ, C. A. et al. Influence of amount and parceling of nitrogen fertilizer on productivity and industrial revenue of sweet corn (Zea mays L.). Australian Journal of Crop Science, Melbourne, v. 9, n. 10, p. 895-900, 2015.

IUSS WORKING GROUP WRB. World reference base for soil resources 2014, update 2015 international soil classification system for naming soils and creating legends for soil maps. WORLD SOIL ed. Rome: FAO, 2015. 203 p.

JHA, S. K.; SINGH, N. K.; AGRAWAL, P. K. Complementation of sweet corn mutants: a method for grouping sweet corn genotypes. Journal of Genetics, Bangalore, v. 95, n. 1, p. 183-187, 2016.

JIN, T. et al. The genetic architecture of zinc and iron content in maize grains as revealed by QTL mapping and meta-analysis. Breeding Science, Tokyo, v. 63, n. 3, p. 317-24, 2013.

JIN, X. et al. Effects of nitrogen stress on the photosynthetic $\mathrm{CO} 2$ assimilation, chlorophyll fluorescence, and sugar-nitrogen ratio in corn. Scientific Reports, London, v. 5, s/n., p. 1-9, 2015.

KWIATKOWSKI, A.; CLEMENTE, E.; SCAPIM, C. A. Agronomic traits and chemical composition of single hybrids of sweet corn. Horticultura Brasileira, Brasília, v. 29, n. 4, p. 531-536, 2011.

LEAL, A. J. F. et al. Adubação nitrogenada para milho com o uso de plantas de cobertura e modos de aplicação de calcário. Revista Brasileira de Ciência do Solo, Viçosa, v. 37, n. 2, p. 491-501, 2013.

MALAVOLTA, E.; VITTI, G. C.; OLIVEIRA, S. A. Avaliação do estado nutricional das plantas: princípios e aplicações. 2. ed. Piracicaba, SP: Potafós, 1997. 319 p.

OKUMURA, R. S. et al. Effects of nitrogen rates and timing of nitrogen topdressing applications on the nutritional and agronomic traits of sweet corn. Journal of Food, Agriculture and Environment, Helsinki, v. 12, n. 2, p. 391-398, 2014.

OLIVEIRA, E. L. Milho. In: OLIVEIRA, E. L. (Ed.). Sugestão de adubação e calagem para culturas de interesse econômico no estado do Paraná. Londrina: IAPAR, 2003. v. 1, cap. 09, p. 22 -23 .

RENGEL, Z.; GRAHAM, R. D. Importance of seed $\mathrm{Zn}$ content for wheat growth on $\mathrm{Zn}$-deficient soil.
Plant and Soil, The Hague, v. 173, n. 2, p. 259-266, 1995.

REYES, F. C. et al. Delivery of prolamins to the protein storage vacuole in maize aleurone cells. The Plant Cell, Rockville, v. 23, n. 2, p. 769-84, 2011.

RITCHIE, S. W.; HANWAY, J. J.; BENSON, G. O. How a corn plant develops. Special Re ed. Ames: Iowa State University of Science and Technology, 1993. $21 \mathrm{p}$.

SANTOS, P. M. et al. Avaliação da qualidade fisiológica de sementes de milho-doce pelo teste de envelhecimento acelerado. Revista Brasileira de Sementes, Londrina, v. 24, n. 1, p. 91-96, 2002.

SCHAARSCHMIDT, F.; VAAS, L. Analysis of Trials with Complex Treatment Structure Using Multiple Contrast Tests. Hort Science, Alexandria, v. 44, n. 1, p. 188-195, 2009.

SHARIFI, R. S.; NAMVAR, A. Effects of time and rate of nitrogen application on phenology and some agronomical traits of maize (Zea mays L.) Biologija, Gedimino, v. 62, n. 1, p. 35-45, 2016.

SILVA, P. R. F. et al. Grain yield and kernel crude protein content increases of maize hybrids with late nitrogen side-dressing. Scientia Agricola, Piracicaba, v. 62, n. 5, p. 487-492, 2005.

VALDERRAMA, M. et al. Adubação nitrogenada na cultura do milho com ureia revestida por diferentes fontes de polímeros. Semina: Ciências Agrárias, Londrina, v. 35, n. 2, p. 659, 2014.

WHITE, P. J.; VENEKLAAS, E. J. Nature and nurture: the importance of seed phosphorus content. Plant and Soil, The Hague, v. 357, n. 1-2, p. 1-8, 2012.

WILSON-JUNIOR, D. O.; MOHAN, S. K. Unique seed quality problems of sh2 sweet corn. Seed Technology, Lincoln, v. 20, n. 2, p. 176-186, 1998.

ZUCARELI, C. et al. Doses e épocas de aplicação de nitrogênio em cobertura na qualidade fisiológica de sementes de milho doce. Revista Brasileira de Sementes, Londrina, v. 34, n. 3, p. 480-487, 2012. 